\title{
BAR OPENING HOURS, ALCOHOL CONSUMPTION AND WORKPLACE ACCIDENTS
}

\author{
NICOLAU MARTIN BASSOLS \\ CENTRE FOR RESEARCH IN HEALTH AND ECONOMICS \\ UNIVERSITAT POMPEU FABRA \\ JUDIT VALL CASTELLO \\ UNIVERSITAT DE BARCELONA, INSTITUT D'ECONOMIA DE BARCELONA (IEB) \& \\ CENTRE FOR RESEARCH IN HEALTH AND ECONOMICS \\ UNIVERSITAT POMPEU FABRA
}

April 2018

\begin{abstract}
It is widely proven that individuals that consume more alcohol are also much more likely to suffer from a working accident. However, this observed correlation may be due to other unobserved factors affecting both alcohol consumption and working accidents (such as the type of job). Thus, in this paper we establish the causal impact of alcohol consumption on working accidents by exploiting a reduction in Spanish bar opening hours that was introduced progressively throughout regions and time. We first show that the policy effectively reduced working accidents. Although there may be many channels by which bar closing hours affect working accidents, we provide evidence that alcohol consumption, which stands as one of these potential channels, is also reduced after the introduction of the policy. Our paper is the first one to provide evidence that stricter closing times for bars causally reduce accidents at work. This is important from a policy point of view as working accidents stand as a very important determinant of productivity levels and entail very high costs in terms of health and disability.
\end{abstract}




\section{Introduction}

In this paper we analyze the causal effect of a policy that reduced bar opening hours in Spain on workplace accidents. Furthermore, we also study the impact of this policy on several proxies of alcohol consumption: household expenditure in bars, self-assessed alcohol consumption as well as hospitalizations due to excessive alcohol consumption. Our results show that reducing bar opening hours causes a decrease in both working accidents as well as alcohol consumption. Thus, we provide the first evidence on the existence of spill over effects of restricting the timing of alcohol sales on the probability of suffering from a working accident. We also show that these effects are heterogeneous across gender and economic sectors.

This analysis is important for several reasons: first, workplace accidents entail massive economic and social costs, affecting not only individuals involved in the accident but also the society as a whole. According to Takala et al. (2014) in 2012, 2.3 million individuals died worldwide due to workplace related accidents. For the different countries, this implied an average economic cost between $1.8 \%$ and $6 \%$ of their GDP. Second, we focus on a country, Spain, which stands at a relatively negative position with respect to its European neighbours regarding workplace safety. Tejedor (2006) examines differences in workplace accidents among EU15 countries for the years 1996 and 2003 and concludes that, in almost all outcomes, Spain was at the back tail of workplace safety standards. For instance, during the period analyzed Spain was the country with the largest number of workplace accidents that required three or more days of sick leave in order to recover. Regarding mortal workplace accidents, Spain was behind the average in the EU15 and almost tripled the number of accidents in which at least one person dies with respect to countries such as Sweden or the UK. Finally, even if there is a large body of literature that reports a strong positive correlation between alcohol consumption and workplace accidents (Van Charante et al. 1990, Zwerling et al. 1996, Wells 1999 amongst others) causality has not yet been established.

Our identification strategy is based on a policy that reduced bar opening hours from 6am to 23.30am in Spain. This represents a strong reduction on the number of hours that bars can remain open and, thus, may have affected the probability of suffering a working accident. There are many channels through which limiting the number of opening hours for bars can result in reductions in workplace accidents. For example, one argument is that individuals will stop drinking alcohol before which will improve concentration the next day at work. However, there 
could be also alternative explanations that do not entail a reduction in alcohol consumption. For example, individuals could drink the same amount than before (although in a shorter period of time) but, because they go to sleep earlier and get more hours of rest, they could also be in better shape the next day and, thus, avoid having accidents while working. Another argument can be that, even if the amount of alcohol or the number of hours of sleep do not change, if individuals spent at home the time that they would have spent in the bar, then they may potentially be less tired which, in turn, can reduce the probability of suffering a working accident the next day. Additionally, it could even be the case that individuals that do not go to bars are less disturbed by noise at nights and are less exposed to fatigue and, thus, they may be in better shape to work and to avoid a workplace accident. Therefore, it is not feasible for us to identify all the channels potentially operating and in this paper we focus on the effects of the reform on one other outcome (and potentially mediator) which is alcohol consumption.

Thus, we exploit the staggered implementation of the reduction in bar opening hours across regions in Spain in order to identify any causal effect of the policy on working accidents, the expenditure of individuals in bars, self-assessed alcohol consumption and hospitalizations related to alcohol consumption. To be best of our knowledge, this is the first paper that reports a drop in the probability of suffering from a working accident when bars are no longer allowed to remain open until sunrise.

Our paper also contributes to the literature that demonstrates how changes on the timing of alcohol sales reduce the consumption of alcohol by affected individuals (Wicki et al. 2011, Carpenter et al. 2009, Marcus et al. 2015, amongst others). Some of these papers also explore potential spill over effects of these policies such as impaired driver road crashes and driver breath alcohol (Chikritzhs et al. 2006), emergency ward admissions and suspected drunk driving (Ragnarsdottir et al. 2002), fatal traffic accidents (Lovenheim et al. 2011), total accidents, pedestrian accidents, single-vehicle accidents and multi-vehicle accidents (Raymond 1969), traffic crash injuries (Smith 1990), crime rates (Heaton 2012) and workplace absenteeism (Green et al. 2015). We contribute to this literature and provide evidence of another positive spill over effect (a reduction in workplace accidents) of policies that affect alcohol consumption. One important difference of our paper is that we focus on a restriction in bar opening hours while most of the previous literature considers policies that increase opening hours of alcohol selling establishments. Green et. al (2015) examine the effects of the same policy and find a reduction 
on the probability that a worker is absent from work as a result of the restriction in bar opening hours. We go one step further than the paper by Green et al. (2015) and focus on an outcome that has much stronger negative effects in terms of health and disability. Furthermore, we use population level data on everyone who suffered from a working accident, which allows us to get a much finer identification than survey data and we also report the impacts of the policy on alcohol consumption, which was unexplored in Green et al. (2015).

\section{Spanish Context}

Spain is divided into 17 regions (Autonomous Communities). Each of these regions implemented the reduction in bar opening hours at some point between 1994 and 2011. Before the reform, bars in Spain were allowed to open until 6am. This was reduced to 2am-3.30am, depending on the region. The progression of these changes through time and regions can be observed in Table 1 and Figure 1 in the appendix ${ }^{1}$. Both the Table as well as the Figure show the exact timing of the introduction of the reduction in bar opening hours in each region. We can see that the reforms were very staggered over time so that there are no two regions implementing the change at the same time. Thus, in our identification strategy we will make use of this heterogeneous implementation of the reform in order to build a quasi-natural experiment comparing regions that have already implemented the policy against those that have not yet introduced it.

One obvious question that may be asked at this point is the reasons that each region had when taking the decision to implement the reduction in bar opening hours at a specific point in time. In order to understand why different reforms were implemented in such a wide time range it is important to be familiarized with the Spanish political structure. The 17 regional entities in Spain represent first-level political and administrative divisions. Therefore, these different regions can exercise their right to self-government (limited by the constitution and their regional statutes) and can decide on when to implement these types of reforms. It is important to point out that other related policies affecting bars and alcohol consumption (changes in taxation, etc.) can only be implemented at a national level. That is, apart from bar opening hours, other changes implemented in the considered time period were introduced homogenously in all regions at the same time and, therefore, will not impose a threat to our identification strategy (as they will be

\footnotetext{
${ }^{1}$ Table 1 has been extracted from Green et al. (2015). We have slightly modified their original table by adding the regions that were not considered in their paper.
} 
captured by the time fixed effects).

The principal objective of the implementation of these reforms was to reduce problems of social coexistence derived from the activity of bars. These problems referred to the noise, pollution and dirt that agglomerations of individuals generate. This is a notable difference with respect to similar policies studied in the literature (changes in the timing of alcohol sales) which main objective is the reduction in alcohol consumption. ${ }^{2}$ Thus, because the reduction in alcohol consumption was not the prime objective of the reduction in bar opening hours in Spain, we expect the potential endogeneity of the policy to be minimized. That is, our guess is that the timing of the implementation of the policy in each region will not be correlated to previous trends in alcohol consumption in that particular region. Furthermore, it is worth noticing that the policy was not systematically introduced by a concrete political party with a certain ideology. Table 2 in the appendix shows the regional political party at the moment of the implementation of the policy in each region. As it can be seen, there were 6 different political parties in the regional government at the time that the policy was implemented; 8 of them can be considered as left wing parties while 9 of them can be considered as right wing parties. In any case, in the next section we will provide some additional evidence of the exogeneity of the policy in our setting. In order for the policy to be effective, at least two conditions need to be fulfilled: first, bar activity in the country has to be important so that a large number of individuals are potential affected. This condition is fulfilled in the case of Spain as the number of bars per inhabitant is very high with respect to other countries. According to Sans (2016) in 2016 Spain had around 260.000 bars. This corresponds to one bar for every 176 Spaniards and places Spain as the country with the highest number of bars per capita in the world.

Second, restrictions in bar opening hours should be imposed at a time range in which individuals are, in effect, spending time in bars so that forcing bars to close earlier would, indeed, affect the behaviour of Spanish citizens. This condition is also fulfilled as Spaniards nightlife extends until early in the following morning. For instance according to a report of the Drug Addiction Foundation (FAD) published in 2016, in 2004 66.3\% of young individuals reported leaving bars after $3 \mathrm{am}$. Therefore, this suggests that these late night life hours are common in Spain and that restricting bar opening hours until 2.30am or 3.30am affected a time range that was highly used

\footnotetext{
${ }^{2}$ The regional reforms are described in different regional laws (decrees). The justification of this restrictive law differs slightly between regions but all decrees highlight the idea of reducing problems of social coexistence.
} 
by Spaniards.

\section{Data and Strategy}

\subsection{Data}

We make use of six different data sources in order to identify our effects of interest. The first one is register data from the Spanish Social Security administration which includes all individuals that experienced a working accident in Spain at some point between 1990 and 2011. The large time span of the data allows us to include at least 4 years before and 4 years after the implementation of the policy in 16 of the 17 regions in Spain. The only exception is Catalonia that introduced the policy in 2011. The database contains information on all workplace accidents ${ }^{3}$ that occurred in Spain for each of these years and has a total of 273.828 observations ${ }^{4}$. The database also includes information on the economic sector of the injured worker (industrial, construction or services sector ${ }^{5}$ ), the gender of the worker as well as the trimester of the accident. Thus, we collapse the individual data at the level of year, trimester and region following Oreopoulos et al. (2012) so that we transform the repeated cross sectional data into a panel of working accidents in each region over time. As the number of employed individuals changes over time and across regions, we divide the data by the number of employed individuals in each region and time (employment data derived from Spanish National Institute of Statistics, INE). This allows us to generate a rate of workplace accidents per region and trimester-year that we will use as our dependent variable. Additionally we make use of data on the unemployment rate throughout region and time (again trimester and year) in order to control for local business cycle conditions (unemployment data derived from Spanish National Institute of Statistics, INE).

In order to identify the effects of the restriction in bar opening hours on alcohol consumption we make use of three different databases. First, we use survey data from the Spanish Family Expenditure Survey (EPF) for the years 1998 to 2004 (17.763 observations) in order to assess the impact of the reform on expenditure in bars. This survey provides annual information on the nature and destination of consumer spending, as well as on various characteristics related to the

\footnotetext{
${ }^{3}$ Total workplace accidents include severe, very severe and mortal accidents. The number of mortal accidents is too small so as to do a separate analysis including only mortal accidents.

${ }^{4}$ It has to be noted that we do not have a personal identifier so that the database is not a panel but a repeated crosssection.

${ }^{5}$ Regarding the Agricultural sector, it is important to stress that for some regions there are very few observations.

Thus, we exclude the Agricultural sector from the analysis.
} 
living conditions of households. Amongst other information, the survey includes a variable that captures yearly expenditure in bars, which we will use to evaluate the impact of the reform on alcohol consumption. We also use information on yearly expenditure in durable goods in order to perform a placebo test experiment (as expenditure in durable goods should not be affected by changes in bar closing hours).

Second, we also explore the effects of the restriction in bar opening hours on alcohol consumption using data from the Spanish National Health Survey (ENS). The ENS is a survey that is periodically carried out in Spain by the Ministry of Health, Social Services and Equality (MSSSI) and contains information on self-reported health status, life habits and health coverage. We focus on the information regarding self-reported alcohol consumption, which is divided into different types of alcoholic drinks. The ENS is not done on a yearly basis which makes it more complicated to capture the impacts of the policy in a precise way. We pool the data for the years 1995, 1997, 2001, 2003, 2004, 2006 and 2007 which include a total of 83.734 observations.

Finally, we use data on hospitalizations caused by alcohol consumption as a proxy variable for extreme alcohol consumption. This is repeated cross sectional data from the National Institute of Statistics that includes the universe of hospitalizations caused by alcohol consumption that occurred in Spain between 1990 and 2011. ${ }^{6}$ The following diagnostics are included: Mental health disorder and dependency syndrome caused by alcohol consumption, liver diseases caused by alcohol consumption and alcohol poisoning. We consider only individuals aged between 16 and 65 ages old which include a total of 870.061 observations. The database also includes information on gender. Although we are aware that hospitalizations represent an extreme outcome derived from highly abusive alcohol consumption episodes, we think it is interesting to explore the existence of any effects on that variable as the reduction in bar opening hours was relatively large (from 6am to 2am) and can potentially have an impact on this extreme margin. Additionally, if the policy fostered reductions in alcohol-related hospitalizations, then the impacts of the reduction in bar opening hours on health outcomes will potentially be very longlasting. We follow a similar strategy than before and collapse the individual data at the level of year, trimester and region. We next divide it by the population aged 16-65 living in each region in each period of time in order to construct a hospitalization rate that will be used as a dependent

\footnotetext{
${ }^{6} 95.5 \%$ of all Spanish hospitals are included in the database which implies a coverage of $99,5 \%$ of all hospitalizations that occur in Spain. It includes public and private hospitals as well as military centres (around 850 hospitals).
} 
variable. Some descriptive statistics of these databases are presented in Table 3.

\subsection{Identification strategy}

We employ a difference-in-differences (DD) framework, exploiting differences in the timing of adoption of the policy across Spanish regions in order to identify the effects of the reduction in bar opening hours on workplace accidents. We use the same model to estimate the effects of the reform on workplace accidents as well as on the three measures of alcohol consumption:

$$
\begin{gathered}
A_{t r}=\beta_{0}+\beta_{1} \text { Treat }_{t r}+\beta_{2} U R_{t r}+\beta_{3} \text { RegionF }_{r}+\beta_{4} \text { TimeFE }_{t}+\beta_{5} \text { TrimesterF }_{t}+ \\
\beta_{6} \text { Region Specific Time Trend } \\
\text { Rr }
\end{gathered}
$$

In this specification $A_{t r}$ stands for workplace accidents for every 100.000 employed individuals as well as for hospitalizations caused by alcohol consumption for every 100.000 individuals. This information varies across regions, $r$, and over time, $t$, which is captured in trimester-years. When we analyze household expenditure on bars and other durable goods, we use as dependent variable the mean of expenditure (in logs) for each region and time whereas for the self-reported variables on alcohol consumption (from the health survey) the dependent variables are dummies for daily/weekly/monthly consumption of wine, whisky, etc.

Our variable of interest in regression 1 above is Treat. This is a step function taking value one after the policy is adopted and zero before. As the policy is introduced in different trimesters and years in different regions (see Table 1 below), the Treat variable turns 1 at different calendar times in each region although all of them correspond to the period in which the policy is implemented in that particular region. Additionally, year, trimester and region fixed effects are included to control for seasonal and region specific differences in alcohol consumption and workplace accidents as well as for any trends over time affecting the entire Spanish territory. Apart from the nation-wide trends over time in alcohol consumption and workplace accidents, there could also be region specific trends that could be interfering in our identification strategy. Thus, in order to control for these regional trends and be able to credibly isolate the effects of the reduction in bar closing times we also include in (most of) the regressions linear region-specific trends. These are calculated by interacting the dummy variables for each region with a linear time trend. The time trend equals 1-4 for the different trimesters of the first year, 5-8 for the different trimesters of the second year and so forth. Although there is a risk that the linear region 
specific trends will capture part of the effect of our policy of interest, we think it is important to include them in order to correctly isolate the effects of the policy from other unrelated trends at the regional level. Apart from that, we also include an additional time varying control at the regional level, the unemployment rate, in order to capture labour market conditions at the local level. We present the results for several sub-groups of the population, such as gender and sector of economic activity, in an attempt to identify the group most affected by the policy change. We estimate the regression weighting observations by either the total population in each region and time (for alcohol consumption) or the employed population in each region and time (for workplace accidents).

As mentioned above, in this particular setting we believe endogeneity is unlikely to be a problem as the policy was introduced to reduce problems of social coexistence (noise, pollution) that may not be directly linked to high alcohol consumption patterns but more to cultural attitudes. However, we perform several tests in order to provide some evidence of the exogeneity of the timing of implementation of the policy. First, we plot the means of the two main outcome variables (workplace accidents and household expenditure on bars) before and after the implementation of the policy. Second, and similar to the graphical representation of the pre-treatment trends, we estimate an event study model in which we include in the regression three additional dummy variables that capture the trend of the outcome variable one, two and three years before the implementation of the policy.

\section{Results}

We first focus on the results that analyze the impact of the reduction in bar opening hours on workplace accidents which are reported in Tables 4 and 5. The tables have two panels: Panel A presents the main results of the difference-in-difference model while Panel B includes the event study design. Regressions in both panels are estimated for everyone as well as separate regressions are performed for women, men, workers in the industrial, construction and service sectors. Table 4 presents the results of the model without linear region specific trends and we can see that the coefficients that capture the impact of the policy on workplace accidents for employed individuals are all negative. Furthermore, the effect is significant for both men and women as well as individuals working in the service sector. When we focus on the total population, we can see that the reduction in bar closing hours decreased the number of working 
accidents in 2.62 per 100.000 employed individuals. When we compare the size of the effect with the mean of working accidents in the sample (which is 28.03 for the total population) we can see that the policy caused a reduction in workplace accidents by $9 \%$. For woman, the policy reduced working accidents by $15 \%$ and for man by $7 \%$. For the services sector the reduction in working accidents amounted to $11 \%$. It is also important to note that, although it is not significant, the size of the coefficient is very large and negative for the construction sector.

Panel B reports the results of the event study design and we can see that there is no evidence of differential trends in the outcome variable one, two or three years before the implementation of the policy. In order to provide some additional graphical evidence on the exogeneity of the policy implementation with respect to our two main outcomes (working accidents and household expenditure in bars) in figures 2 and 3 we examine the trends for these two variables before and after the regions introduced the policy. We can see that both outcomes follow a relatively stable path before the policy is introduced but drop quite sharply right after the policy is implemented, which occurs in several different calendar years across regions.

As explained in the previous section, although we include fixed effects for regions, years and trimesters, there could also be region specific trends that could be interfering in our identification strategy. Thus, in order to control for these regional trends and be able to credibly isolate the effects of the reduction in bar closing times, in Table 5 we also include in the regressions linear region-specific trends. Although it has been argued that these trends can partially be capturing the impacts of the policy of interest, we believe it is important to include them in our setting as the heterogeneity across regions in Spain is very high. Consequently, the risk of having different trends in working accidents across regions in our setting is non-negligible. For this reason, the rest of the results will include region-specific trends. As it can be seen in Panel A of Table 5 all the results show the similar sign but smaller magnitudes. However, only the coefficient for the construction sector is significant. Not only the coefficient is significant but the size of the effect for this sector of the economy is really big: we estimate that the reduction in bar closing hours decreased working accidents in 6.60 accidents per 100.000 workers, which implies a reduction by $18.3 \%$. We believe that these results are consistent with the profile of workers employed in the construction sector in Spain which are mainly young, low educated men that have higher probabilities of drinking and going out at nights than other population groups. ${ }^{7}$ As before, Panel

\footnotetext{
${ }^{7}$ Before the onset of the recent economic crisis, $93.2 \%$ of the workers employed in the construction sector were men
} 
B confirms that trends in working accidents are stable right before the policy is implemented which confirms that there is no evidence of endogeneity in the timing of the policy.

There are many channels through which limiting the number of opening hours for bars can result in reductions in workplace accidents; individuals may stop drinking alcohol which will improve concentration the next day at work or, even if they drink the same amount, they may go to sleep earlier and be more rested so as to avoid having an accident the next day. Another argument can be that, even if the amount of alcohol or the number of hours of sleep do not change, if individuals stay at home instead of being in bars, they may also be more rested and avoid working accidents the next day. Additionally, even non-bar users may be less disturbed by noise at nights and be in better shape to work and to avoid a workplace accident. Therefore, it is not feasible for us to identify all the channels potentially operating and in this paper we focus on the effects of the reform on one other outcome (and potentially mediator) which is alcohol consumption. In order to do that, we use three proxies for alcohol consumption: our main proxy variable is yearly expenditure in bars per household. Apart from that, we also consider two additional proxies for alcohol consumption: self-reported alcohol consumption and hospitalizations caused by excessive alcohol consumption.

The results for yearly expenditure per household are presented in Table 6 which includes the regressions for several types of expenditures. The data comes from the Spanish Family Expenditure Survey. In the first column the dependent variable is the amount of euros (in ln) spent in bars while the rest of columns include the results for expenditures in durable goods, which we will use as placebo tests. These include expenditure in furniture, textiles, big home appliances, small home appliances, crockery and other durable goods. In principle, the reduction in bar opening hours should reduce the money spent in bars but should not affect the amount of household resources spend in these other durable goods. As it can be seen in the first column of Table 6, expenditure in bars was reduced by $13 \%$ as a result of the advancement in bar closing hours. As expected, none of the coefficients capturing the effects of the reform on other durable goods is significant, which reinforces the validity of our estimates and approach, and provides evidence that our results are not driven by other economic or social trends at the regional level at the same time than the introduction of our policy of interest.

and $84 \%$ of them had less than 50 years old (60\% had less than 40 years old). Furthermore, around $25 \%$ of them had primary education or below, $60 \%$ of them had secundary education and only $15 \%$ of them had college education. Data taken from the Spanish Labour Force Survey for the first trimester of 2008. 
We next focus on the results on self-assessed alcohol consumption using data from the Spanish National Health Survey. We use as outcomes dummy variables that capture the consumption of alcoholic drinks and tobacco. In line with the results found with the data on expenditure in bars, we can see in Table 7 that all the diff-diff coefficients are negative pointing towards a reduction in self-reported alcohol consumption. Furthermore, the coefficients for daily and weekly consumption of wine are significant and the effects are stronger for men. This is consistent with the strongest reduction in workplace accidents found for men and the construction sector, which is a sector with a majority of male workers $(93,2 \%$ of workers in the construction sector in Spain are men; Labour Force Survey, first trimester of 2008).

The regressions for the consumption of whisky, liquor, aperitifs and mixed drinks as well as the probability of smoking are also negative but non-significant. These results have to be interpreted with caution as the National Health Survey is not implemented every year. This fact complicates the precise identification of the effects of the reform as, for some of the regions we do not have information in the first or second year of the reform. Thus, the results obtained with this database should be interpreted as a lower bound of the true effects of the policy. Furthermore, the effects of some of the strongest drinks are also difficult to identify with survey data due to the low incidence of its consumption. Even if taking into account the limitations of this dataset, we still identify significant reductions in the consumption of some of the alcoholic drinks considered.

Finally, we focus on an extreme proxy of alcohol consumption which is the hospitalization rate caused by alcohol consumption. We interpret this variable as an extreme outcome of alcohol consumption as it represents episodes of strong alcohol poisoning problems which require a hospitalization to be treated. ${ }^{8}$ We can see in Table 8 that all the coefficients of the diff-diff variable are negative but not significant and that the strongest reduction in alcohol-related hospitalizations is reported again for men. Considering the fact that individuals are more likely to experience the alcohol-related hospitalization episodes during the weekends, we restrict our data to alcoholrelated hospitalizations that occur only on Saturdays and Sundays to try to improve the precision of our estimates. Results are presented in Table 9 and we can observe that they are consistent with Table 8 when we considered hospitalizations occurring during any of the days of the week: all coefficients are negative and stronger in size for men. In fact, in this specification considering

\footnotetext{
${ }^{8}$ The following diagnostics are included: Mental health disorder and dependency syndrome caused by alcohol consumption, liver diseases caused by alcohol consumption and alcohol poisoning.
} 
only weekend hospitalizations we do find a significant negative coefficient for men pointing towards important reductions in alcohol-related hospitalizations during the weekends as a result of the reduction in bar opening hours. More precisely, the reduction in hospitalizations for men is by 0.28 per 100.000 individuals which represents a reduction by $16.5 \%$ with respect to the mean. $^{9}$

As before, we find that the policy reduced alcohol consumption particularly for men, which is the same group that showed significant reductions in self-reported alcohol consumption as well as in workplace accidents (in the construction sector which is predominantly dominated by men; $93,2 \%$ of workers in the construction sector are men).

\section{Conclusions}

In this paper we provide the first causal estimate on the effects of a policy that reduced bar opening hours on workplace accidents and we find that the policy causally decreased working accidents. Thus, we expand on previous literature that focused on the impact of similar policies on different outcomes (such as fatal traffic accidents (Lovenheim et al. 2011), crime rates (Heaton 2012) or workplace absenteeism (Green et al. 2015), among others) by looking at a previously unexplored but rather relevant outcome; working accidents. Accidents at work stand as an important determinant of future health and disability rates and represent an estimated economic cost between $1.8 \%$ and $6 \%$ of the country's GDP. Thus, it has much deeper economic and social impact than absenteeism or crime rates.

In order to identify the effects we exploit the staggered implementation of the reduction in bar opening hours across Spanish regions over time that occurred between 1990 and 2011. Before the reforms, bars were allowed to remain open until 6am while the reform restricted opening times until 2-3.30am, depending on the region.

Furthermore, we also provide evidence that the reduction in bar closing times fostered a reduction in the consumption of alcohol. We use several measures to capture alcohol consumption patterns: household expenditures in bars, self-assessed alcohol consumption and

\footnotetext{
${ }^{9}$ We have run alternative specifications for smaller diagnoses groups of alcohol-related hospitalizations and all the coefficients are also negative although some of the significance levels are lost due to the lower number of observations included.
} 
hospitalizations due to excessive alcohol consumption.

We use both survey data on household's expenditures and self-assessed alcohol consumption as well as rich administrative databases from the Social Security administration for both working accidents as well as hospitalizations which allows us to include the universe of individuals that suffer from a work accident or a hospitalization episode.

We believe that our results are important from a policy perspective because they show the existence of positive health and labor market spillover effects of reducing bar closing hours and, thus, they provide valuable guidance for policy makers considering the introduction of these types of reforms. 


\section{References}

Carpenter, Christopher S., and Daniel Eisenberg (2009). "Effects of Sunday Sales Restrictions on Overall and Day-Specific Alcohol Consumption: Evidence From Canada," Journal of Studies on Alcohol and Drugs, 70: 126-133.

Chikritzhs, T., \& Stockwell, T. (2006). The impact of later trading hours for hotels on levels of impaired driver road crashes and driver breath alcohol levels. Addiction, 101(9),

Green Heyword \& Navarro (2013) Did liberalising bar hours decrease traffic accidents? Journal of Health Economics, 35, 189-198.

Green, C. P., \& Navarro Paniagua, M. (2015). Play Hard, Shirk Hard? The Effect of Bar Hours Regulation on Worker Absence. Oxford Bulletin of Economics and Statistics.

Heaton (2012) Sunday liquor laws and crime. Journal of public economics, 96, 42-52.

Los jóvenes españoles son más "marchosos" que hace unos años pero ahora vuelven a casa más temprano (2016), Retrieved from FAD at: http://www.fad.es/node/7738

Lovenheim , M. F. \& Steefel, D. P. (2011) Do Blue Laws Save Lives? The Effect of Sunday Alcohol Sales Bans on Fatal Vehicle Accidents. Association for Public Policy Analysis and Management. Journal of Policy Analysis and Management, 30(4), 798-820.

Marcus, J., \& Siedler, T. (2015). Reducing binge drinking? The effect of a ban on late-night offpremise alcohol sales on alcohol-related hospital stays in Germany. Journal of Public Economics, 123, 55-77.

Oreopoulos, P., Von Wachter, T., \& Heisz, A. (2012). The short-and long-term career effects of graduating in a recession. American Economic Journal: Applied Economics, 4(1), 1-29.

Ragnarsdottir, T., Kjartansdottir, A., \& Davidsdottir, S. (2002). Effect of extended alcohol serving-hours in Reykjavik. The effects of Nordic alcohol policies: What happens to drinking and harm when control systems change.

Raymond, A. (1969). Ten o'clock closing-The effect of the change in hotel bar closing time on road accidents in the metropolitan area of Victoria. Australian Road Research, 3(10).

Sans A. (2016). ¿Por qué entramos (ahora) en un bar?, Retrieved from A. C. Nielsen Company: http://www.lainformacion.com/2016/06/22/bares.pdf?hash=bea381f0e084c44c47ab8690765eb6c $771939 \mathrm{ba} 8$

Smith, D. I. (1990). Effect on casualty traffic accidents of changing Sunday alcohol sales legislation in Victoria, Australia Journal of Drug Issues, 20(3), 417-426.

Takala, J., Hämäläinen, P., Saarela, K. L., Yun, L. Y., Manickam, K., Jin, T. W., \& Lin, G. S. (2014). Global estimates of the burden of injury and illness at work in 2012. Journal of 
occupational and environmental hygiene, 11(5), 326-337.

Tejedor, M. (2006). Evolución de los accidentes de trabajo entre 1996 y 2003, INSHT. 37-2006, 25-34

Van Charante \& Mulder, P. G. (1990). Perceptual acuity and the risk of industrial accidents. American journal of epidemiology, 131(4), 652-663.

Vingilis, E., McLeod, A. I., Seeley, J., Mann, R. E., Beirness, D., \& Compton, C. P. (2005). Road safety impact of extended drinking hours in Ontario. Accident Analysis \& Prevention, 37(3), 549-556.

Wells, S., \& Macdonald, S. (1999). The relationship between alcohol consumption patterns and car, work, sports and home accidents for different age groups.Accident Analysis \& Prevention, 31(6), 663-665.

Wicki, M., \& Gmel, G. (2011). Hospital admission rates for alcoholic intoxication after policy changes in the canton of Geneva, Switzerland. Drug and alcohol dependence, 118(2), 209-215.

Zwerling, C., Sprince, N. L., Wallace, R. B., Davis, C. S., Whitten, P. S., \& Heeringa, S. G. (1996). Alcohol and occupational injuries among older workers.Accident Analysis \& Prevention, 28(3), 371-376. 
Table 1. Implementation of the policy for the different regions and time ${ }^{10}$

\begin{tabular}{|c|c|c|c|}
\hline $\begin{array}{l}\text { Regions in } \\
\text { Spain (CCAA) }\end{array}$ & $\begin{array}{l}\text { Law } \\
\text { came } \\
\text { into } \\
\text { force }\end{array}$ & Law & Closing time \\
\hline Andalucía & $\begin{array}{l}1^{\text {st }} \\
\text { quarter } \\
2003\end{array}$ & $\begin{array}{l}\text { Ley } 13 / 1999 \text {, de } 15 \text { de diciembre, de Espectáculos Públicos y } \\
\text { Actividades Recreativas de Andalucía (BOE núm. 15, de } 18 \text { de } \\
\text { enero), modificada por la Ley 10/2002, de } 21 \text { de diciembre (BOE } \\
\text { núm. 14, de } 16 \text { de enero de 2003). }\end{array}$ & 3:00am* \\
\hline Aragon & $\begin{array}{l}1^{\text {st }} \\
\text { quarter } \\
2006\end{array}$ & $\begin{array}{l}\text { Ley } 11 / 2005 \text {, de } 28 \text { de diciembre, reguladora de los espectáculos } \\
\text { públicos, actividades recreativas y establecimientos públicos de la } \\
\text { Comunidad Autónoma de Aragón (BOE núm. } 23 \text {, de } 27 \text { de enero). }\end{array}$ & 3:30am* \\
\hline $\begin{array}{l}\text { Canary } \\
\text { Islands }\end{array}$ & $\begin{array}{l}2^{\text {nd }} \\
\text { quarter } \\
2002\end{array}$ & $\begin{array}{l}\text { Ley } 1 / 1998 \text {, de } 8 \text { de enero, de Régimen Jurídico de los } \\
\text { Espectáculos Públicos y Actividades Clasificadas (BOE núm. } 27 \text {, } \\
\text { de } 31 \text { de enero). Corrección de errores en BOE núm. } 68 \text {, de } 20-03- \\
98 \text { y modificada por la Ley } 2 / 2002 \text {, de } 27 \text { de marzo (BOE núm. } \\
97 \text {, de } 23 \text { de abril). }\end{array}$ & 3:30am \\
\hline Cantabria & $\begin{array}{l}3^{\text {rd }} \\
\text { quarter } \\
1997\end{array}$ & $\begin{array}{l}\text { Decreto } 72 / 1997 \text {, de } 7 \text { julio. Establece el régimen general de } \\
\text { horarios de establecimientos y espectáculos públicos y actividades } \\
\text { recreativas. Consejería Presidencia. BO. Cantabria } 23 \text { julio } 1997 \text {, } \\
\text { núm. } 146 .\end{array}$ & 2:00am \\
\hline $\begin{array}{l}\text { Comunidad de } \\
\text { Madrid }\end{array}$ & $\begin{array}{l}3^{\text {rd }} \\
\text { quarter } \\
2002\end{array}$ & $\begin{array}{l}\text { Ley 17/1997, de } 4 \text { de julio, de Espectáculos Públicos y } \\
\text { Actividades Recreativas (BOE núm. } 98 \text {, de } 24 \text { de abril de } 1998 \text { ), } \\
\text { modificada por la Ley } 24 / 1999 \text {, de } 27 \text { de diciembre (BOE núm. } \\
48 \text {, de } 25 \text { de febrero de } 2000 \text { ), por la Ley } 5 / 2000 \text {, de } 8 \text { de mayo } \\
\text { (BOE núm. 126, de } 26 \text { de mayo) y por la Ley } 5 / 2002 \text {, de } 27 \text { de } \\
\text { junio (BOE núm. 176, de } 24 \text { de julio). }\end{array}$ & 3:00am** \\
\hline Castilla Leon & $\begin{array}{l}4^{\text {th }} \\
\text { quarter } \\
2006\end{array}$ & $\begin{array}{l}\text { Ley } 7 / 2006 \text {, de } 2 \text { de octubre, de espectáculos públicos y } \\
\text { actividades recreativas de la Comunidad de Castilla y León (BOE } \\
\text { núm. 272, de } 14 \text { de noviembre). }\end{array}$ & 3:00am \\
\hline $\begin{array}{l}\text { Castilla la } \\
\text { mancha }\end{array}$ & $\begin{array}{l}1^{\text {st }} \\
\text { quarter } \\
1996\end{array}$ & $\begin{array}{l}\text { Orden de } 4 \text { de enero de 1996, que regula el horario general de los } \\
\text { espectáculos públicos y actividades recreativa. }\end{array}$ & $\begin{array}{l}1.30 \mathrm{am} \text { or } \\
2.30 \mathrm{am} * * * *\end{array}$ \\
\hline Catalunya & $\begin{array}{l}4^{\text {th }} \\
\text { quarter } \\
2011\end{array}$ & $\begin{array}{l}\text { Orden INT/358/2011, de } 19 \text { de diciembre, por la que se regulan } \\
\text { los horarios de los establecimientos abiertos al público, de los } \\
\text { espectáculos públicos y de las actividades recreativas sometidos a } \\
\text { la Ley } 11 / 2009 \text {, de } 6 \text { de julio, de regulación administrativa de los } \\
\text { espectáculos públicos y de las actividades recreativas, y a su } \\
\text { Reglamento. }\end{array}$ & 2:30am \\
\hline Extremadura & $\begin{array}{l}\text { 3th } \\
\text { quarter } \\
1996\end{array}$ & $\begin{array}{l}\text { Orden de } 16 \text { septiembre } 1996 \text {. Espectáculos públicos y actividades } \\
\text { recreativas. Horarios de apertura y cierre de los establecimientos. } \\
\text { Consejería presidencia y trabajo. D.O. Extremadura } 19 \text { septiembre } \\
\text { 1996, núm. } 109 \text {. }\end{array}$ & $\begin{array}{l}1: 30 \mathrm{am} \text { or } \\
2: 30 \mathrm{am} * * * *\end{array}$ \\
\hline Galicia & $\begin{array}{l}2^{\text {nd }} \\
\text { quarter } \\
2005\end{array}$ & $\begin{array}{l}\text { Orden de } 16 \text { de junio de } 2005 \text { por la que se determinan los } \\
\text { horarios de apertura y cierre de espectáculos y establecimientos } \\
\text { públicos en la Comunidad Autónoma de Galicia. }\end{array}$ & 2:30am \\
\hline Murcia & $\begin{array}{l}1^{\text {st }} \\
\text { quarter } \\
1994\end{array}$ & $\begin{array}{l}\text { Circular No 2/1994, sobre horario de cierre para los } \\
\text { establecimientos públicos, espectáculos y fiestas para la } \\
\text { comunidad autónnoma de la región de Murciao. (B.O.E. 15-3- }\end{array}$ & $\begin{array}{l}2: 30 \mathrm{am} \text { or } \\
3: 30 \mathrm{am}^{* * * * *}\end{array}$ \\
\hline
\end{tabular}

${ }^{10}$ Table extracted from Green et al. (2015). We have slightly modified the original table by including some regions that were missing in the Green et al. paper. 


\begin{tabular}{|c|c|c|c|}
\hline & & 1994) & \\
\hline Navarra & $\begin{array}{l}2^{\text {nd }} \\
\text { quarter } \\
2004\end{array}$ & $\begin{array}{l}\text { Ley Foral 2/1989, de } 13 \text { de marzo, Reguladora de los } \\
\text { Espectáculos Públicos y Actividades Recreativas (BOE núm. } 84 \text {, } \\
\text { de } 8 \text { de abril), modificada por la Ley Foral } 26 / 2001 \text {, de } 10 \text { de } \\
\text { diciembre (BOE núm. } 39 \text {, de } 14 \text { de febrero de } 2002 \text { ). } 27 \text { de } \\
\text { octubre de 2003, 656/2003 Decreto Foral (BON145 de } \\
\text { 14/11/2003), entrada en vigor } 1 \text { de abril de } 2004 \text {. }\end{array}$ & 3:30am** \\
\hline $\begin{array}{l}\text { Comunidad } \\
\text { Valenciana }\end{array}$ & $\begin{array}{l}1^{\text {st }} \\
\text { quarter } \\
2004\end{array}$ & $\begin{array}{l}\text { Ley de las Cortes Valencianas 4/2003, de } 26 \text { de febrero, de los } \\
\text { Espectáculos Públicos, Actividades Recreativas y } \\
\text { Establecimientos Públicos (BOE núm. } 81 \text {, de } 4 \text { de abril). Ley } \\
4 / 2003 \text {, de } 26 \text { de febrero, Orden de } 19 \text { de diciembre de } 2003 \text {, } \\
\text { entrada en vigor en } 2004 \text {. }\end{array}$ & 3:30am \\
\hline $\begin{array}{l}\text { Balearic } \\
\text { Islands }\end{array}$ & $\begin{array}{l}2^{\text {nd }} \\
\text { quarter } \\
1999\end{array}$ & $\begin{array}{l}\text { Ley 7/1999, de } 8 \text { de abril, de Atribución de Competencias a los } \\
\text { Consejos Insulares de Menorca y de Eivissa WE Formentera en } \\
\text { materia de Espectáculos Públicos y Actividades Recreativas (BOE } \\
\text { núm. 124, de } 25 \text { de mayo). }\end{array}$ & 3:00am \\
\hline La Rioja & $\begin{array}{l}4^{\text {th }} \\
\text { quarter } \\
2000\end{array}$ & $\begin{array}{l}\text { Ley } 4 / 2000 \text {, de } 25 \text { de octubre, de Espectáculos Públicos y } \\
\text { Actividades Recreativas. (BOE núm. 287, de } 30 \text { de noviembre). }\end{array}$ & $3: 30 * *$ \\
\hline Pais Vasco & $\begin{array}{l}3^{\text {rd }} \\
\text { quarter } \\
1998\end{array}$ & $\begin{array}{l}\text { Ley 4/1995, de } 10 \text { de noviembre, de la Comunidad Autónoma del } \\
\text { País Vasco, sobre normas reguladoras de Espectáculos Públicos y } \\
\text { Actividades Recreativas (BOE núm. 230, de } 1 \text { de diciembre). } \\
\text { 210/1998 de } 28 \text { de Julio } 1998 \text {. }\end{array}$ & 2:00am* \\
\hline Asturias & $\begin{array}{l}1^{\text {st }} \\
\text { quarter } \\
2005\end{array}$ & $\begin{array}{l}\text { Ley } 8 / 2002 \text {, de } 21 \text { de octubre, de Espectáculos Públicos y } \\
\text { Actividades Recreativas. (BOE núm. 278, de } 20 \text { de noviembre). } \\
\text { Decreto 90/2004, de } 11 \text { de noviembre, por el que se regula el } \\
\text { regimen de horarios de los establecimientos, locales e } \\
\text { instalaciones para espectáculos públicos y actividades recreativas } \\
\text { en el Principado de Asturias. }\end{array}$ & 3:30am* \\
\hline
\end{tabular}

Notes: * On Fridays and Saturdays bars are allowed to stay open for one hour more. ** On Fridays and Saturdays bars are allowed to stay open for half an hour more. *** On Fridays, Saturdays and the night before a holidays are allowed to stay open for half an hour more $* * * *$ The first one corresponds to the winter opening times, the second one to the summer opening times. Source: Table extracted from Green et al. (2015) modified by the authors by adding up some missing regions. 
Figure 1. Implementation of the policy for the different regions and time.

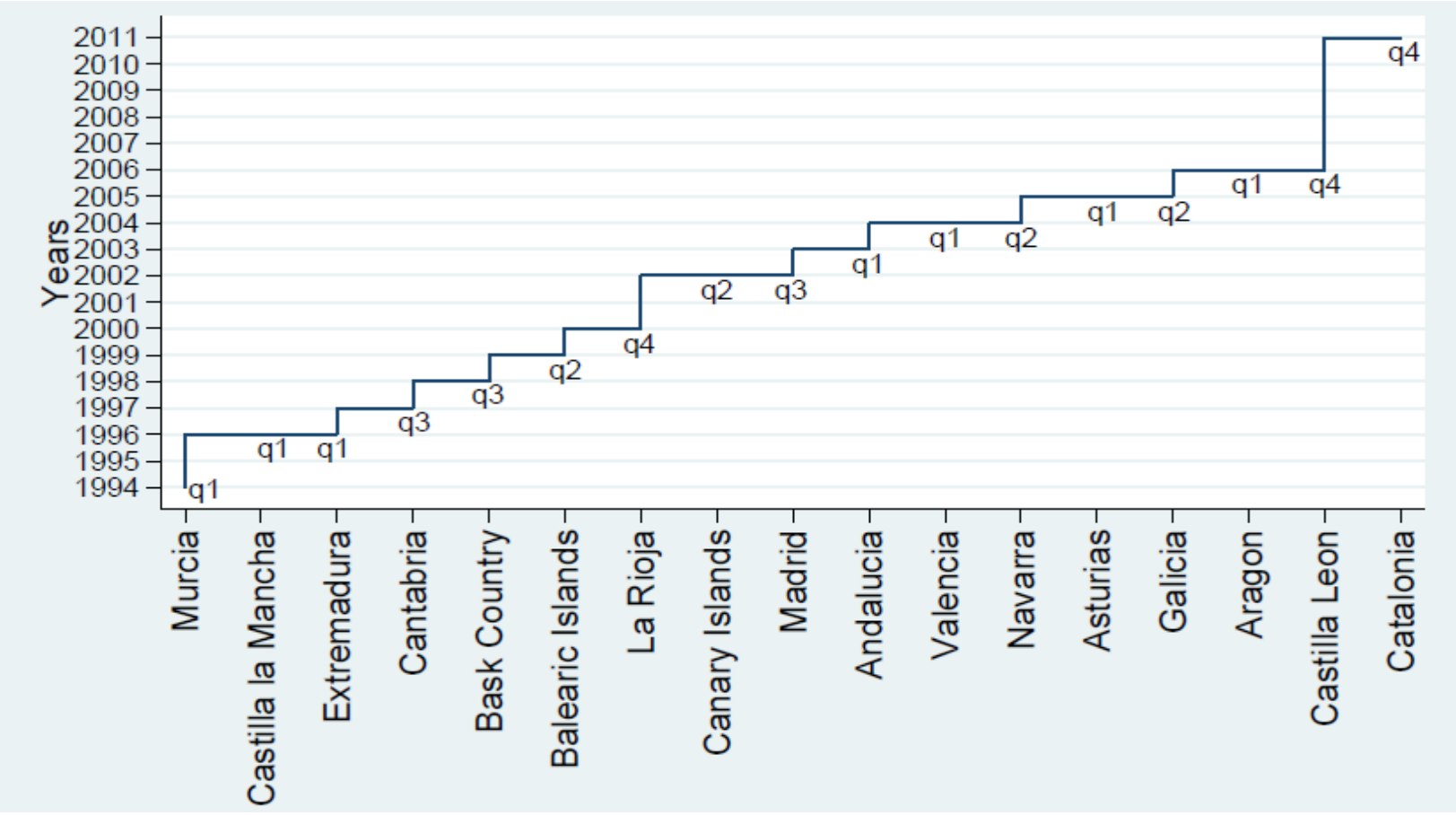

Source: Own elaboration by the authors. 
Table 2. Political party in the regional government at the time that the policy was implemented.

\begin{tabular}{|c|c|c|}
\hline Region & Year of Policy Implementation & Political Party Year of the Policy Implementation \\
\hline Andalucía & 1st quarter 2003 & PSOE (left) \\
\hline Aragon & 1st quarter 2006 & PSOE (left) \\
\hline Asturias & 1st quarter 2005 & PSOE (left) \\
\hline Balearic Islands & 2nd quarter 1999 & PSOE (left) \\
\hline Canary Islands & 2nd quarter 2002 & CC (right) \\
\hline Cantabria & 3th quarter 1997 & PP (right) \\
\hline Castile Leon & 4th quarter 2006 & PP (right) \\
\hline Castile La Mancha & 4st quarter 1996 & PSOE (left) \\
\hline Catalonia & 4th quarter 2011 & CIU (right) \\
\hline Valencia & 1st quarter 2004 & $\mathrm{PP}$ (right) \\
\hline Extremadura & 1st quarter 1996 & PSOE (left) \\
\hline Galicia & 2nd quarter 2005 & PSOE (left) \\
\hline Madrid & 3th quarter 2002 & PP (right) \\
\hline Murcia & 1st quarter 1994 & PSOE (left) \\
\hline Navarra & 2nd quarter 2004 & UPN (right) \\
\hline Bask Country & 3th quarter 1998 & EAJ-PNV (right) \\
\hline La Rioja & 4th quarter 1998 & PP (right) \\
\hline
\end{tabular}

Source: Own elaboration by the authors.

Table 3. Descriptive statistics. Workplace accidents, hospitalizations caused by excessive alcohol consumption, self-reported consumption of alcohol (survey data).

\begin{tabular}{|c|c|c|c|c|c|c|}
\hline & Total & Man & Woman & Services & Construction & Industry \\
\hline \multicolumn{7}{|c|}{ Workplace accidents for every 100.000 employed individuals } \\
\hline Mean & 22.70 & 7.68 & 31.02 & 27.94 & 35.08 & 16.63 \\
\hline Observations & 1,496 & 1,496 & 1,496 & 1,496 & 1,496 & 1,496 \\
\hline \multicolumn{7}{|c|}{ Annual Spending per Household (in euros) } \\
\hline \multicolumn{7}{|c|}{ Bars } \\
\hline Mean & 148.50 & - & - & - & - & - \\
\hline Observations & 119 & - & - & - & - & - \\
\hline \multicolumn{7}{|l|}{ Textiles } \\
\hline Mean & 185.65 & - & - & - & - & - \\
\hline Observations & 119 & - & - & - & - & - \\
\hline \multicolumn{7}{|c|}{ Big House Appliances } \\
\hline Mean & 34.74 & - & - & - & - & - \\
\hline Observations & 119 & - & - & - & - & - \\
\hline \multicolumn{7}{|c|}{ Small House Appliances } \\
\hline Mean & 184.15 & - & - & - & - & - \\
\hline Observations & 119 & - & - & - & - & - \\
\hline
\end{tabular}




\begin{tabular}{|c|c|c|c|c|c|c|}
\hline Crockery & & & & & & \\
\hline Mean & 31.63 & - & - & - & - & - \\
\hline Observations & 119 & - & - & - & - & - \\
\hline Others & & & & & & \\
\hline Mean & 153.53 & - & - & - & - & - \\
\hline Observations & 119 & - & - & - & - & - \\
\hline Self-reported a & mption $(\mathrm{c}$ & ny variab & & & & \\
\hline Daily Wine Co & & & & & & \\
\hline Mean & 0.11 & 0.07 & 0.16 & - & - & - \\
\hline Observations & 78,570 & 43,300 & 35,269 & - & - & - \\
\hline Weekly Wine & & & & & & \\
\hline Mean & 0.17 & 0.12 & 0.23 & - & - & - \\
\hline Observations & 78,570 & 43,300 & 35,269 & - & - & - \\
\hline Monthly Wine & & & & & & \\
\hline Mean & 0.20 & 0.15 & 0.26 & - & - & - \\
\hline Observations & 78,570 & 43,300 & 35,269 & - & - & - \\
\hline Weekly Whisk & & & & & & \\
\hline Mean & 0.02 & 0.01 & 0.03 & - & - & - \\
\hline Observations & 78,570 & 43,300 & 35,269 & - & - & - \\
\hline Monthly Whis & ion & & & & & \\
\hline Mean & 0.03 & 0.01 & 0.05 & - & - & - \\
\hline Observations & 78,570 & 43,300 & 35,269 & - & - & - \\
\hline Daily smoker & & & & & & \\
\hline Mean & 0.27 & 0.21 & 0.35 & - & - & - \\
\hline Observations & 78,570 & 43,300 & 35,269 & - & - & - \\
\hline Hospitalization & excessive & hol const & $\mathrm{n}$ for ever & 000 & & \\
\hline All Weekdays & & & & & & \\
\hline Mean & 23.67 & 14.43 & 31.00 & - & - & - \\
\hline Observations & 1,496 & 1,496 & 1,496 & - & - & - \\
\hline Weekends & & & & & & \\
\hline Mean & 1.48 & 0.96 & 1.88 & - & - & - \\
\hline Observations & 1,496 & 1,496 & 1,496 & - & - & - \\
\hline
\end{tabular}

Source: Register data from the Spanish Social Security administration for the years 1990-2011. Spanish Family Expenditure Survey (EPF) for the years 1998 to 2004. Spanish National Health Survey (ENS) for the years 1995, 1997, 2001, 2003, 2004, 2006 and 2007. Register data from the the Hospital Morbidity Survey for the years 1990-2011. 
Figure 2. Percentage of workplace accidents per 100.000 workers. Three years before and three years after the implementation of the policy.

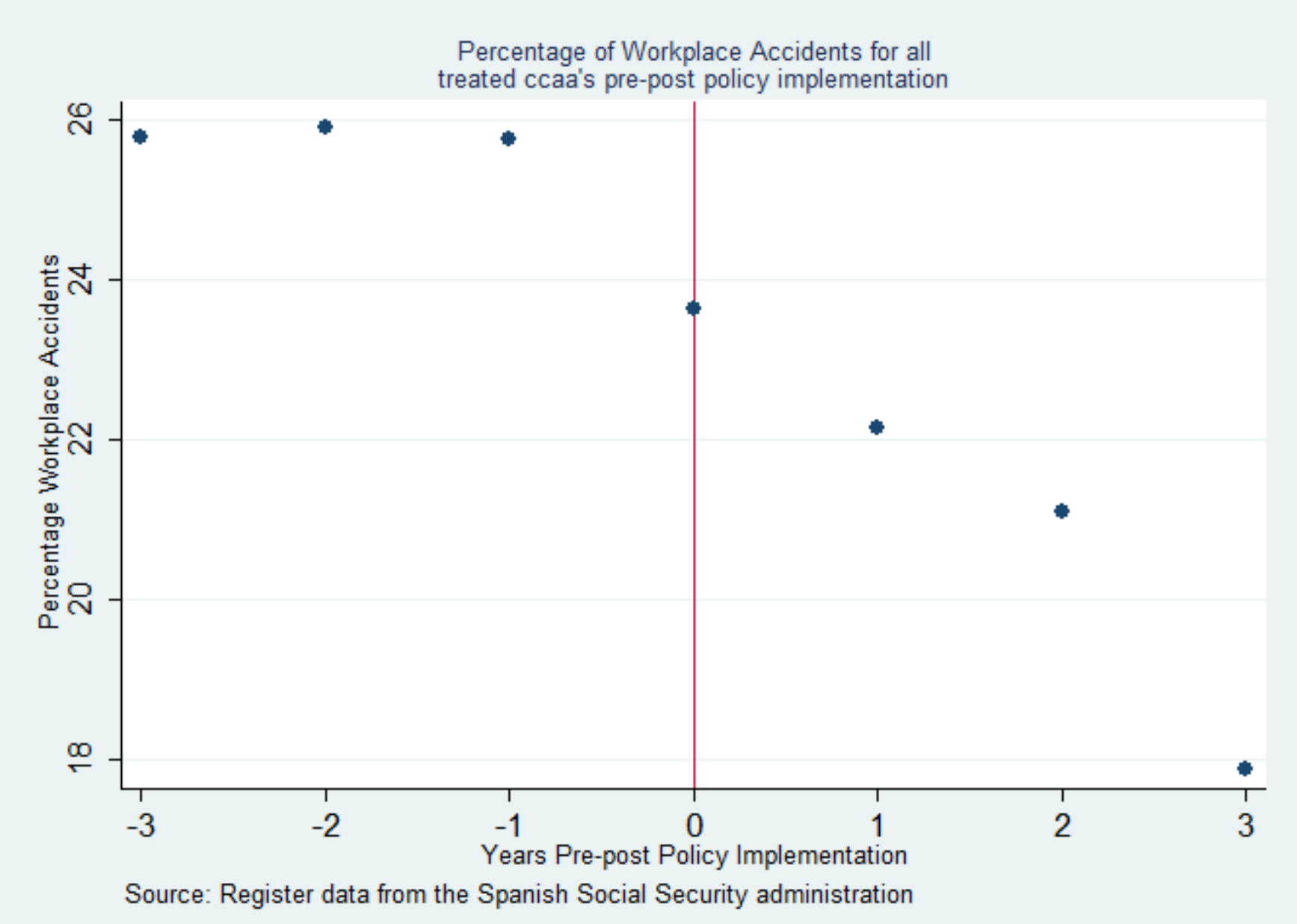

Notes: As the reduction in bar closing hours was introduced in several different calendar years across regions, we centre the year of policy implementation to 0 so that it is the same for all regions. Then, we plot the mean of workplace accidents per 100.000 employed individuals up to 3 years before and three years after the implementation of the reduction in bar closing hours in all regions in order to explore the trends in the outcome variable before and after the implementation of the policy.

Source: Register data from the Spanish Social Security administration for years 1990-2011. 
Figure 3. Average Annual Expenditure in Bars per Household (in Euros). Three years before and three years after the implementation of the policy.

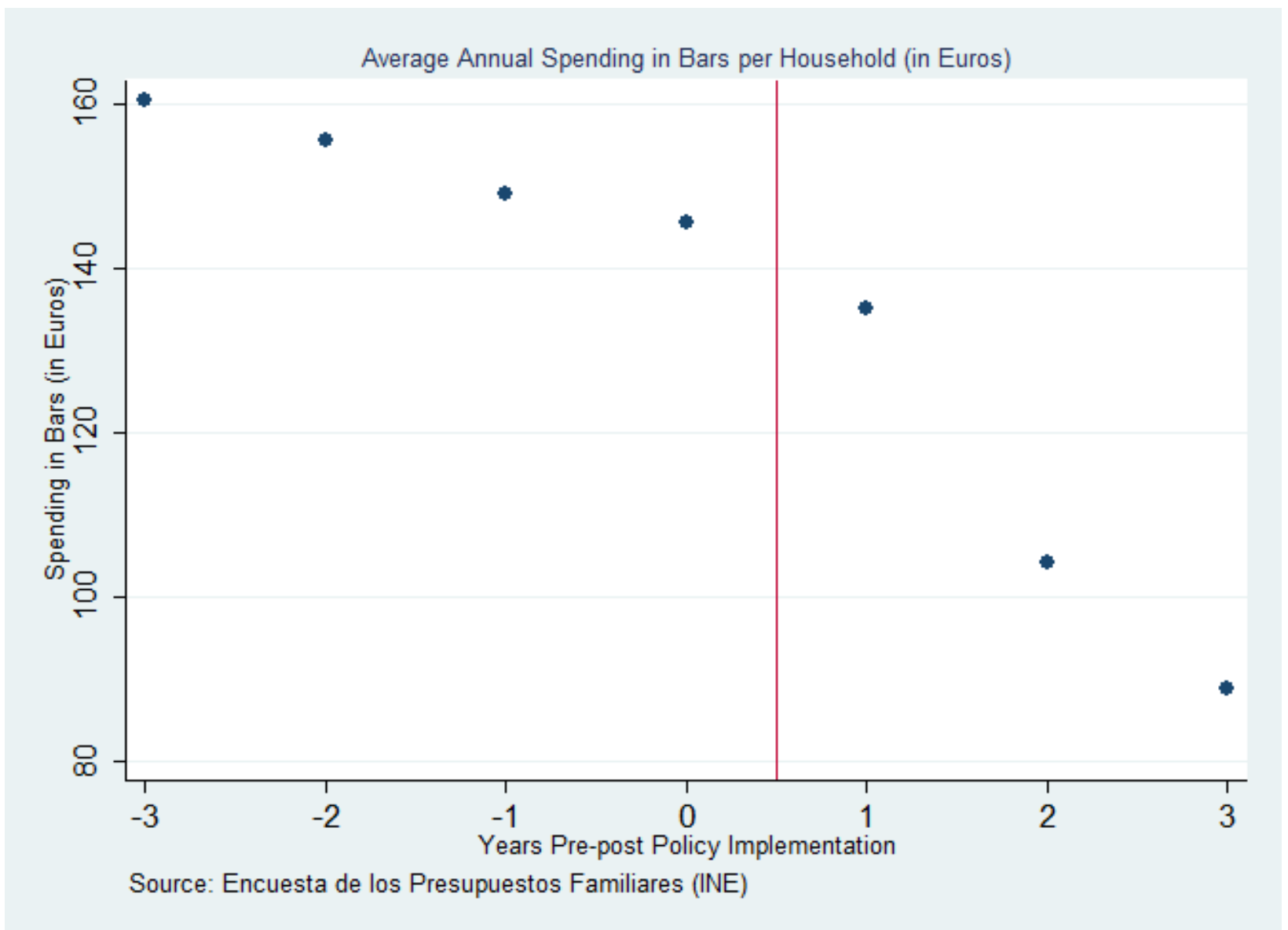

Notes: As the reduction in bar closing hours was introduced in several different calendar years across regions, we centre the year of policy implementation to 0 so that it is the same for all regions. Then, we plot the average annual expenditure in bars per households for up to 3 years before and three years after the implementation of the reduction in bar closing hours in all regions in order to explore the trends in the outcome variable before and after the implementation of the policy.

Source: Spanish Family Expenditure Survey (EPF) for the years 1998 to 2004. 
Table 4. Workplace accidents for every 100.000 employed individuals (without Region Specific Time Trends).

\begin{tabular}{|c|c|c|c|c|c|c|}
\hline \multicolumn{7}{|c|}{ Panel A: Difference-in-Difference } \\
\hline & Total & Woman & Man & Industry & Construction & Services \\
\hline \multirow[t]{2}{*}{ Treat } & $-2.62 * *$ & $-1.49^{*}$ & $-2.89 * *$ & -3.01 & -4.61 & $-2.43^{* *}$ \\
\hline & (1.223) & $(0.779)$ & (1.277) & (3.605) & $(2.868)$ & $(0.965)$ \\
\hline \multicolumn{7}{|l|}{ Panel B: Event Study Design } \\
\hline \multirow[t]{2}{*}{ Pre3 } & 0.77 & 0.40 & 1.13 & 0.21 & 1.98 & 0.47 \\
\hline & $(0.916)$ & $(0.472)$ & $(1.351)$ & $(14.016)$ & $(3.435)$ & $(0.545)$ \\
\hline \multirow[t]{2}{*}{ Pre2 } & 1.40 & 0.47 & $2.16^{*}$ & 1.41 & 4.68 & 0.28 \\
\hline & $(0.930)$ & $(0.582)$ & $(1.235)$ & $(1.958)$ & (3.684) & $(0.604)$ \\
\hline \multirow[t]{2}{*}{ Pre1 } & 0.41 & 0.45 & 0.68 & -1.15 & 1.51 & 0.41 \\
\hline & $(1.147)$ & $(0.536)$ & $(1.504)$ & $(2.170)$ & $(5.707)$ & $(0.746)$ \\
\hline \multirow[t]{2}{*}{ Treat } & -2.14 & -1.22 & -2.12 & -2.97 & -2.94 & -2.20 \\
\hline & (1.343) & $(0.888)$ & (1.348) & (5.197) & $(3.375)$ & (1.413) \\
\hline Region FE & YES & YES & YES & YES & YES & YES \\
\hline Year FE & YES & YES & YES & YES & YES & YES \\
\hline Trim FE & YES & YES & YES & YES & YES & YES \\
\hline Region Specific Time Trend & NO & NO & NO & NO & NO & NO \\
\hline Mean Pre-Policy & 28.03 & 9.62 & 37.60 & 31.39 & 35.92 & 21.75 \\
\hline Observations & 1,496 & 1,496 & 1,496 & 1,496 & 1,496 & 1,496 \\
\hline
\end{tabular}

Notes: In panel A the dependent variable is the percentage of workplace accidents every 100.000 employed individuals at the regional and trimester-year level. The regressions control for the unemployment rate at the local level in each period as well as for time and region fixed effects. Treat is a dummy variable equal to 1 for the periods and regions for which the reduction in bar closing hours is implemented and 0 otherwise and it captures the impact of the policy. Panel B is an event study model similar to Panel A but additionally including dummy variables for 1, 2 or 3 years before the implementation of the policy. Robust standard errors clustered at the regional level in parenthesis and the $\mathrm{p}$-value of the wild bootstrap with 500 replications in brackets.

*significant at $10 \%$; * significant at $5 \%$; ***significant at $1 \%$.

Source: Register data from the Spanish Social Security administration for the years 1990-2011. 
Table 5. Workplace accidents for every 100.000 employed individuals (with Region Specific Time Trend).

\begin{tabular}{|c|c|c|c|c|c|c|}
\hline \multicolumn{7}{|c|}{ Panel A: Difference-in-Difference } \\
\hline & Total & Woman & Man & Industry & Construction & Services \\
\hline \multirow[t]{2}{*}{ Treat } & -1.74 & -1.06 & -1.96 & -0.56 & $-6.60 * *$ & -1.60 \\
\hline & $(1.378)$ & $(0.661)$ & $(1.656)$ & $(2.531)$ & $(2.922)$ & (1.206) \\
\hline \multicolumn{7}{|l|}{ Panel B: Event Study Design } \\
\hline \multirow[t]{2}{*}{ Pre3 } & 0.73 & 0.34 & 1.11 & $2.01 * *$ & -0.16 & 0.68 \\
\hline & $(0.915)$ & $(0.512)$ & $(1.106)$ & $(0.935)$ & $(0.908)$ & $(0.705)$ \\
\hline \multirow[t]{2}{*}{ Pre2 } & 1.48 & 0.48 & 2.28 & $3.53 * *$ & 2.16 & 0.64 \\
\hline & $(1.188)$ & $(0.748)$ & $(1.577)$ & $(1.645)$ & $(3.776)$ & $(1.272)$ \\
\hline \multirow[t]{2}{*}{ Pre1 } & 0.63 & 0.52 & 0.95 & 1.49 & -1.38 & 0.91 \\
\hline & $(0.932)$ & $(0.715)$ & $(1.085)$ & $(1.836)$ & $(2.842)$ & (1.236) \\
\hline \multirow[t]{2}{*}{ Treat } & -0.92 & -0.65 & -0.72 & 1.40 & -6.56 & -0.92 \\
\hline & $(1.934)$ & $(0.987)$ & $(2.855)$ & $(2.404)$ & $(4.307)$ & (1.919) \\
\hline Region FE & YES & YES & YES & YES & YES & YES \\
\hline Year FE & YES & YES & YES & YES & YES & YES \\
\hline Trim FE & YES & YES & YES & YES & YES & YES \\
\hline Region Specific Time Trend & YES & YES & YES & YES & YES & YES \\
\hline Mean Pre-Policy & 28.03 & 9.62 & 37.60 & 31.39 & 35.92 & 21.75 \\
\hline Observations & 1,496 & 1,496 & 1,496 & 1,496 & 1,496 & 1,496 \\
\hline
\end{tabular}

Notes: In panel A the dependent variable is the percentage of workplace accidents every 100.000 employed individuals at the regional and trimester-year level. The regressions control for the unemployment rate at the local level in each period, for time and region fixed effects as well as for region-specific linear trends. Treat is a dummy variable equal to 1 for the periods and regions for which the reduction in bar closing hours is implemented and 0 otherwise and it captures the impact of the policy. Panel B is an event study model similar to Panel A but additionally including dummy variables for 1, 2 or 3 years before the implementation of the policy. Robust standard errors clustered at the regional level in parenthesis and the p-value of the wild bootstrap with 500 replications in brackets.

*significant at 10\%; **significant at 5\%; ***significant at $1 \%$.

Source: Register data from the Spanish Social Security administration for the years 1990-2011. 
Table 6. Annual Spending in Bars and Durable Goods per Household (in $\ln ($ Euros)).

\begin{tabular}{|c|c|c|c|c|c|c|c|}
\hline & Bars & Furniture & Textiles & $\begin{array}{l}\text { Big Home } \\
\text { Appliances }\end{array}$ & $\begin{array}{c}\text { Small Home } \\
\text { Appliances }\end{array}$ & Crockery & Others \\
\hline Treat & $\begin{array}{l}-0.13 * * \\
(0.060)\end{array}$ & $\begin{array}{c}-0.09 \\
(0.130)\end{array}$ & $\begin{array}{c}-0.02 \\
(0.066)\end{array}$ & $\begin{array}{c}0.09 \\
(0.177)\end{array}$ & $\begin{array}{c}0.10 \\
(0.135)\end{array}$ & $\begin{array}{c}-0.05 \\
(0.129)\end{array}$ & $\begin{array}{c}-0.01 \\
(0.104)\end{array}$ \\
\hline Region FE & YES & YES & YES & YES & YES & YES & YES \\
\hline Year FE & YES & YES & YES & YES & YES & YES & YES \\
\hline Trim FE & YES & YES & YES & YES & YES & YES & YES \\
\hline $\begin{array}{l}\text { Region Time } \\
\text { Trend }\end{array}$ & YES & YES & YES & YES & YES & YES & YES \\
\hline $\begin{array}{l}\text { Mean Pre- } \\
\text { Policy (in } \\
\text { euros) }\end{array}$ & 183.31 & 216.22 & 237.80 & 182.87 & 76.01 & 173.66 & 810.78 \\
\hline Observations & 91 & 91 & 91 & 91 & 91 & 91 & 91 \\
\hline \multicolumn{8}{|c|}{$\begin{array}{l}\text { Bootstrap standard errors in parentheses } \\
* * * p<0.01, * * p<0.05, * \mathrm{p}<0.10 \\
\text { Notes: The dependent variables are the yearly average household spending per region in bars, furniture, textiles, big and small } \\
\text { home appliances, crockery and other expenditure types. The regressions control for the unemployment rate at the local level in } \\
\text { each period, for time and region fixed effects as well as for region-specific linear trends. Treat is a dummy variable equal to } 1 \text { for } \\
\text { the periods and regions for which the reduction in bar closing hours is implemented and } 0 \text { otherwise and it captures the impact of } \\
\text { the policy. Robust standard errors clustered at the regional level in parenthesis and the p-value of the wild bootstrap with } 500 \\
\text { replications in brackets. } \\
\text { *significant at } 10 \% ; * * \text { significant at } 5 \% \text {; ***significant at } 1 \% \text {. }\end{array}$} \\
\hline
\end{tabular}


Table 7. Effects of the policy on self-reported alcohol consumption.

\begin{tabular}{|c|c|c|c|}
\hline & Total & Woman & Man \\
\hline \multicolumn{4}{|l|}{ Daily Wine Consumption } \\
\hline Treat & $\begin{array}{c}-0.02 \\
(0.016)\end{array}$ & $\begin{array}{c}-0.01 \\
(0.016)\end{array}$ & $\begin{array}{l}-0.04^{*} \\
(0.021)\end{array}$ \\
\hline \multicolumn{4}{|l|}{ Weekly Wine Consumption } \\
\hline Treat & $\begin{array}{c}-0.02 \\
(0.014)\end{array}$ & $\begin{array}{c}-0.01 \\
(0.020)\end{array}$ & $\begin{array}{c}-0.04^{* *} \\
(0.017)\end{array}$ \\
\hline \multicolumn{4}{|l|}{ Monthly Wine Consumption } \\
\hline Treat & $\begin{array}{c}-0.01 \\
(0.019)\end{array}$ & $\begin{array}{c}0.00 \\
(0.007)\end{array}$ & $\begin{array}{c}-0.03 \\
(0.022)\end{array}$ \\
\hline \multicolumn{4}{|l|}{ Weekly Whisky Consumption } \\
\hline Treat & $\begin{array}{c}0.00 \\
(0.004)\end{array}$ & $\begin{array}{c}0.00 \\
(0.002)\end{array}$ & $\begin{array}{c}-0.00 \\
(0.010)\end{array}$ \\
\hline \multicolumn{4}{|c|}{ Monthly Whisky Consumption } \\
\hline Treat & $\begin{array}{c}-0.01 \\
(0.023)\end{array}$ & $\begin{array}{c}-0.01 \\
(0.007)\end{array}$ & $\begin{array}{c}-0.01 \\
(0.051)\end{array}$ \\
\hline \multicolumn{4}{|l|}{ Daily smoker } \\
\hline Treat & $\begin{array}{c}-0.01 \\
(0.007)\end{array}$ & $\begin{array}{c}-0.00 \\
(0.011)\end{array}$ & $\begin{array}{c}-0.02 \\
(0.012)\end{array}$ \\
\hline Region FE & YES & YES & YES \\
\hline Year FE & YES & YES & YES \\
\hline Trim FE & YES & YES & YES \\
\hline $\begin{array}{l}\text { Region Specific Time Trend } \\
\text { Observations }\end{array}$ & $\begin{array}{c}\text { YES } \\
78,570\end{array}$ & $\begin{array}{c}\text { YES } \\
43,300\end{array}$ & $\begin{array}{c}\text { YES } \\
35,269\end{array}$ \\
\hline \multicolumn{4}{|c|}{$\begin{array}{l}\text { Bootstrap standard errors in parentheses } \\
* * * \text { p }<0.01, * * \mathrm{p}<0.05, * \mathrm{p}<0.10 \\
\text { Notes: The dependent variables are dummy variables for daily, weekly and monthly consumption of wine, whisky and tobacco. } \\
\text { The regressions control for the unemployment rate at the local level in each period, for time and region fixed effects as well as for } \\
\text { region-specific linear trends. Treat is a dummy variable equal to } 1 \text { for the periods and regions for which the reduction in bar } \\
\text { closing hours is implemented and } 0 \text { otherwise and it captures the impact of the policy. Robust standard errors clustered at the } \\
\text { regional level in parenthesis and the p-value of the wild bootstrap with } 500 \text { replications in brackets. } \\
\text { *significant at } 10 \% ; * * \text { significant at } 5 \% \text {; } * * \text { significant at } 1 \% \text {. } \\
\text { Source: Spanish National Health Survey (ENS) for the years } 1995,1997,2001,2003,2004,2006 \text { and } 2007 \text {. }\end{array}$} \\
\hline
\end{tabular}


Table 8. Hospitalizations caused by excessive alcohol consumption for every $\mathbf{1 0 0 . 0 0 0}$ individuals.

\begin{tabular}{|c|c|c|c|}
\hline Difference-in-Difference & Total & Woman & Man \\
\hline Treat & $\begin{array}{c}-3.00 \\
(2.031)\end{array}$ & $\begin{array}{c}-2.72 \\
(1.816)\end{array}$ & $\begin{array}{c}-3.36 \\
(2.307)\end{array}$ \\
\hline $\begin{array}{l}\text { Region FE } \\
\text { Year FE } \\
\text { Trim FE } \\
\text { Region Specific Time Trend } \\
\text { Mean Pre-Policy } \\
\text { Observations }\end{array}$ & $\begin{array}{c}\text { YES } \\
\text { YES } \\
\text { YES } \\
\text { YES } \\
18.64 \\
1,496\end{array}$ & $\begin{array}{l}\text { YES } \\
\text { YES } \\
\text { YES } \\
\text { YES } \\
10.65 \\
1,496\end{array}$ & $\begin{array}{l}\text { YES } \\
\text { YES } \\
\text { YES } \\
\text { YES } \\
23.29 \\
1,496\end{array}$ \\
\hline
\end{tabular}

Bootstrap standard errors in parentheses

$* * * \mathrm{p}<0.01, * * \mathrm{p}<0.05, * \mathrm{p}<0.10$

Notes: The dependent variable is the number of hospitalizations caused by alcohol consumption for every 100.000 individuals in each region and trimester-year. The regressions control for the unemployment rate at the local level in each period, for time and region fixed effects as well as for region-specific linear trends. Treat is a dummy variable equal to 1 for the periods and regions for which the reduction in bar closing hours is implemented and 0 otherwise and it captures the impact of the policy. Robust standard errors clustered at the regional level in parenthesis and the p-value of the wild bootstrap with 500 replications in brackets.

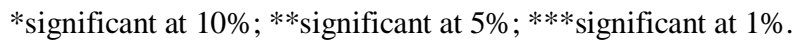

Source: Register data from the the Hospital Morbidity Survey for the years 1990-2011.

Table 9. Hospitalizations caused by excessive alcohol consumption for every 100.000 individuals. Sample including only weekend hospitalizations.

\begin{tabular}{l|c|c|c}
\hline \hline Difference-in-Difference & \multicolumn{3}{c}{ Woman } \\
\hline \\
Treat & Total & -0.12 & $-0.28^{* *}$ \\
& & $(0.105)$ & $(0.135)$ \\
& $(0.117)$ & & YES \\
Region FE & & YES & YES \\
Year FE & YES & YES & YES \\
Trim FE & YES & YES & YES \\
Region Specific Time Trend & YES & YES & 1.70 \\
Mean Pre-Policy & 1.40 & 0.86 & 1,496 \\
Observations & 1,496 & 1,496 & \\
\hline
\end{tabular}

Notes: The dependent variable is the number of hospitalizations caused by alcohol consumption for every 100.000 individuals in each region and trimester-year. The sample is restricted to include only hospitalizations during the weekend. The regressions control for the unemployment rate at the local level in each period, for time and region fixed effects as well as for region-specific linear trends. Treat is a dummy variable equal to 1 for the periods and regions for which the reduction in bar closing hours is implemented and 0 otherwise and it captures the impact of the policy. Robust standard errors clustered at the regional level in parenthesis and the p-value of the wild bootstrap with 500 replications in brackets.

*significant at $10 \%$; **significant at $5 \%$; ***significant at $1 \%$.

Source: Register data from the the Hospital Morbidity Survey for the years 1990-2011. 